https://doi.org/10.38129/Ann.Yur.Ist.2020.4.4.92

УДК: 351[352/354]:323.2+342+172

\title{
ДЕЦЕНТРАЛІЗАЦІЯ В ДІї: ПОЛІТИЧНІ, ФІЛОСОФСЬКІ ТА ЮРИДИЧНІ АСПЕКТИ
}

\author{
ДМИТРО ВЕРБІВСЬКИЙ (Житомир, Україна) * \\ КОСТЯНТИН ВЕРГЕЛЕС (Вінниця, Україна) * \\ ЛЮДМИЛА ГОРОХОВА (Житомир, Україна) *
}

Актуальність проблеми та їі зв'язок із важливими науковими чи практичними завданнями. В Україні тривають процеси децентралізації влади, які намагаються вивести країну на європейський рівень державотворення та демократії. Реформування органів місцевого самоврядування та територіальної організації влади в країні триває понад 5 років і має позитивні результати. Важливим завданням реформи є обрання правильного шляху побудови сильної країни з демократичним управлінням, передачею владних повноважень територіальним органам i забезпеченням широкої участі громадян в управлінні справами держави й суспільства в цілому. Проблема реформування місцевого самоврядування $є$ міждисциплінарною і потребує вивчення ї̈ різних аспектів в сучасних умовах. Саме тому наше дослідження присвячене політичним, правовим і філософським аспектам децентралізації влади в Україні.

Аналіз останніх досліджень $i$ публікацій з окресленої проблеми. Теоретичні й практичні аспекти процесів децентралізації влади й розвитку місцевого самоврядування досліджують як вітчизняні так і закордонні фахівці різних галузей науки. Так, питання адміністративно-територіальної організації децентралізації вивчають Б. Данилишин ${ }^{1}$, В. Мамонова, А. Ткачук, В. Храмов та інші. Організаційно-правовим та політико-правовим аспектам окресленої проблеми присвячені праці В. Авер'янова, Г. Атаманчука, В. Бакуменка, М. Братковського, М. Будника, I. Грицяка, Н. Нижника, О. Скрипнюк, І. Трофімової тощо. О. Бориславська, Ж. Ведель, А. Школик

1 Данилишин Б. Як децентралізувати управління в Україні [Електронний ресурс] /Б. Данилишин // Економічна правда. - 2015. - 13 липня. - Режим доступу : :http://www.epravda.com.ua/columns/2015/07/13/550472/ 
вивчають i узагальнюють зарубіжний досвід реформування влади. В Дубківський, О. Крайник, І. Сікора та інші аналізують фінансові питання децентралізації. Філософські аспекти реформування місцевого самоврядування й становлення громадянського суспільства були предметом наукових розвідок К. -О. Апеля, М. Вебера, А. де Токвіля, Ф. Фукуями, Ю. Хабермаса тощо. Проте, незважаючи на низку наукових розвідок, питання політологічних, філософських та юридичних аспектів децентралізації влади залишається актуальним у сучасних умовах і потребує подальших досліджень.

Формулювання мети і завданъ. Метою статті є дослідження політичних, правових та філософських аспектів процесів впровадження реформ децентралізації влади та ії ролі в посиленні демократії в Україні. Досягнення поставленої мети передбачає розв' язання таких дослідницьких завдань: аналіз сучасної ситуації в Україні щодо реалізації реформування місцевого самоврядування; з' ясування окремих аспектів реалізації зазначеної реформи, а саме: політичних, конституційно-правових та філософських; визначення досягнень та недоліків на даному етапі реформи децентралізації.

Виклад основного матеріалу дослідження з обгрунтуванням отриманих наукових результатів. Від перших днів впровадження реформи децентралізації влади в Україні й донині важливою темою дебатів є питання масштабів, швидкості, наслідків та перешкод на шляху створення об'єднаних територіальних громад. Актуальність i необхідність втілення в життя окресленої реформи засвідчує й публічна нарада Президента України В. Зеленського з керівництвом новообраної Верховної Ради України, проведена ще 2 вересня 2019 року, на якій обговорювалися заходи необхідні для якнайшвидшого завершення процесів децентралізації. Одним із рішень наради було завершення навесні 2020 року конституційно-правового оформлення реформи i затвердження нового адміністративнотериторіального устрою держави. Найважливішим кроком задля цього i ключовим етапом впровадження реформи децентралізації влади визначено внесення змін до Основного Закону держави щодо розподілу публічної влади (державної та місцевої) на конституційному рівні².

Можливі зміни до Конституції України та їх доцільність, а також пріоритети Уряду щодо реформування місцевого самоврядування

\footnotetext{
2 Про попереднє схвалення законопроекту про внесення змін до Конституції України щодо децентралізації влади [Електронний ресурс] : Постанова Верховної Ради України від 31 серпня 2015 року № 656-VIII. - Режим доступу : http://zakon4.rada.gov.ua/laws/show/656-19.
} 
обговорювалися 22 жовтня 2019 року на публічній презентації, організованій народними депутатами України, Міністерством розвитку громад та територій України у співпраці з Комітетом Верховної Ради України з питань організації державної влади, місцевого самоврядування, регіонального розвитку та містобудування. Серед завдань у запропонованій концепції було закріплення системи адміністративно-територіального устрою держави, яка включає 3 рівні, а саме територіальні громади (базовий рівень), округи / повіти (субрегіональний рівень), регіони, до складу яких увійдуть сучасні області та Автономна Республіка Крим. Проте питання реалізації запропонованих змін поки що не вирішено, перешкодою є навіть термінологічна невизначеність оскільки Комітет Верховної Ради та відповідний профільний Підкомітет 3 адміністративно-територіального устрою держави пропонує використання терміну «округ», а профільне Міністерство - терміну «повіт».

Актуальність проблеми засвідчує й їі обговорення на міжнародному рівні, зокрема на XIII Економічному форумі «Европа - Україна», який відбувся 4-5 лютого 2020 року в Жешуві Підкарпатського воєводства в Польщі. Виступаючи на форумі, один із авторів і провідний експерт реформи Анатолій Ткачук, зауважив на тому, що «за уряду Володимира Гройсмана було розуміння - щоби вийти на чергові місцеві вибори в останню неділю жовтня 2020 року необхідно розробити та ухвалити закон «Про адміністративнотериторіальний устрій», не «прив' язуючи» його до зміни Конституції. Йдеться про 100 \% створення територіальних громад - вочевидь, уже не на засадах добровільного об'єднання, а виконання державою відповідної функції. Зазначимо від себе - це правильно в тому сенсі, що вона не належить місцевому самоврядуванню, а лише була йому делегована (фактично) державою для проведення реформ»3. Слід погодитися 3 думкою доповідача, про те, що нині наша держава фактично «поділена навпіл», оскільки майже 70 \% громадян (ті, що проживають в ОТГ та містах обласного значення) вже користуються перевагами децентралізації, зокрема фінансової, а решта близько 30 \% живуть в умовах «вертикального» підходу щодо вирішення питань через райдержадміністрації.

Відповідно, влада і уряд повинні якомога швидше відреагувати на вирішення окреслених питань, адже частина суспільства живе в нормальних умовах, а решта приречена на «адміністративне» існування, так як одним із

${ }^{3}$ Бойко Володимир. Повертаємось до плану «Б»? - [Електронний ресурс]. Режим доступу до до джерела: https://m.day.kyiv.ua/uk/article/svitovidyskusiyi/povertayemos-do-planu-b 
завдань у програмі діяльності Кабміну (постанова від 29.09.2019 № 849) був пункт, згідно якого «100\% жителів України проживають у спроможних громадах»4. Крім того, частина кроків на цьому шляху, принаймні станом на сьогодні, відстають від запланованого графіка. Так, юрист Сергій Буров, який є експертом з питань децентралізації, зазначав: «Наступним кроком та фактично завершенням реформи децентралізації в Україні є ухвалення Верховною Радою закону, яким має бути затверджений новий адміністративнотериторіальний устрій держави (березень 2020), та проведення Центральною виборчою комісією на цій підставі «перших» місцевих виборів на всій території України (травень 2020)»5. Тому, аналізуючи сучасну ситуачію, ми можемо говорити принаймні про відставання у строках, а відповідно й відстрочення завершення юридичного оформлення процесів децентралізації влади в Україні. Крім того, процедура внесення змін до Конституції України є ускладненою не лише часовими межами, а й відбувається в певній послідовності, що вимагає дотримання особливих параметрів і вимог.

Проте вирішення окреслених питань не терпить втрати часу, оскільки важливість результатів реформи є значно ширшою, ніж зміна місцевого та регіонального рівнів організації управління. Йдеться про створення простору для виявлення ініціативи та відповідальності громадян і керівників як одного iз інструментів місцевого та регіонального розвитку. Крім того, окреслені процеси є необхідними і в розрізі політичних аспектів проблеми, позаяк $є$ засобами протидії країні-агресору та спрямованій проти України політиці.

Також важливим у цьому плані є питання про закріплення особливого статусу окремих районів Донецької та Луганської областей, позаяк 31 грудня 2019 року припинив діяти закон України про ОРДЛО, пролонгування якого пропонував президент РФ під час переговорів у Нормандському форматі в Парижі. Саме зазначений політичний чинник, викликав неабияку реакцію українського суспільства після внесення у 2016 році законопроекту про зміни до Конституції України у частині особливого статусу Донецької та Луганської областей. Тому народні депутати нині повинні враховувати історичний досвід та помилки минулого і схвалити зміни до Основного Закону лише юридично

\footnotetext{
4 Буровий Сергій - юрист, експерт 3 децентралізації. [Стара нова децентралізація [Електронний ресурс]. Режим доступу: https://radnyk.org/noviny/stara-novadeczentralizacziya/

5 Буровий Сергій - юрист, експерт 3 децентралізації. [Стара нова децентралізація [Електронний ресурс]. Режим доступу: https://radnyk.org/noviny/stara-novadeczentralizacziya/
} 
прийнятні у контексті реформи децентралізації, які матимуть позитивні результати i дозволять завершити нормативно-правове забезпечення реформування місцевого самоврядування на конституційному рівні. Певну надію i сподівання на позитивні результати дає домовленість лідерів нормандської четвірки про те, що передумови для проведення місцевих виборів в ОРДЛО мають бути створені впродовж 4 місяців.

Проте, окремі фахівці мають певні побоювання щодо готовності Президента Зеленського до закріплення особливого статусу окремих районів Донецької і Луганської областей на постійній основі, що означатиме перспективу створення російського анклаву в Україні, який перешкоджатиме інтеграції України до ЄС і НАТО. Про останнє, зокрема, зазначав Народний депутат України Олег Синютка в ефірі телеканалу «Прямий». Депутат вважає це великою дипломатичною помилкою, яка буде мати дуже негативні наслідки для України ${ }^{6}$. Тема набула масового обговорення і викликала неабиякий резонанс, зокрема 3 цього приводу на своїй сторінці у Facebook Народний депутат України Микола Княжицький зазначив: «підпис президента України Володимира Зеленського під підсумковим документом Нормандського саміту у Парижі - це фіксація зобов'язань України щодо федералізації Донбасу та проведення там виборів без виконання безпекових вимог» ${ }^{7}$. Ситуація знову постає двояко, позаяк Київ наполягає на тому, щоб вибори на Донбасі відбувалися лише після роззброєння бойовиків і повернення контролю над східним кордоном Україні, тоді як Росія наполягає на дострокових виборах до повернення контролю над кордоном.

Аналіз сучасної ситуації засвідчує невирішеність окресленої проблеми, оскільки навіть публічне обговорення урядом Олексія Гончарука на початку 2020 року зазнало бурхливої та болісної реакції як з боку суспільства так і з боку самих авторів правок до Конституції України. Обурення викликали питання «нагляду префектур над діяльністю місцевого самоврядування» й «ліквідація списку областей» на зміну яких було запропоновано адміністративно-

${ }^{6}$ Особливий статус Донбасу на постійній основі перетворить ОРДЛО на російський анклав - "СС". [Електронний ресурс]. Режим доступу до джерела: https://www.5.ua/polityka/osoblyvyi-status-donbasu-na-postiinii-osnovi-peretvorytordlo-na-rosiiskyi-anklav-yes-204507.html

7 Зеленський підписався на федералізацію і вибори в ОРДЛО на умовах Путіна Княжицький. [Електронний ресурс]. Режим доступу до джерела: https://www.5.ua/polityka/zelenskyi-pidpysavsia-na-federalizatsiiu-i-vybory-v-ordlona-umovakh-putina-kniazhytskyi-204433.html 
територіальні одиниці, статус яких визначає Верховна Рада Україна, а отже відповідно такий закон уможливлював надання особливого статусу навіть для «ОРДЛО».

Крім того, на нашу думку, вагомим результатом у вирішенні питань щодо можливих змін у законодавстві з питань децентралізації влади було обговорення проблеми і «спроба збереження місцевого самоврядування на субрегіональному рівні (нові райони, округи чи повіти - як вже їх назвуть) 3 закріпленням за ним низки функцій», що відстоював один із авторів реформи Анатолій Ткачук на XIII Економічному форумі «Европа - Україна» в Польщі. Неодноразові зустрічі з польськими войтами та бурмістрами (сільськими та міськими головами) дозволили зрозуміти на польському досвіді недоречність впровадження в Україні таких змін оскільки «не існує функцій субрегіонального рівня, які не можна було б закріпити або за базовим (гміна чи громада) рівнем, або ж за регіональним (воєводство чи область) ${ }^{8}$.

Бурхлива реакція громадян, голів ОТГ, експертів та представників Заходу призвела до втручання президента в ситуацію і відкликання зазначеного законопроекту. I як результат - час знову втрачено, хоча експерти зазначають про те, що цілком виправданим є «рішення парламенту, котре дає змогу уряду розробити та подати на його затвердження проєкт звичайного закону про нову структуру адміністративно-територіального устрою на базовому (територіальної громади) рівні» ${ }^{9}$. Зазначене рішення врешті-решт уможливило ухвалення необхідної постанови 17 липня 2020 року, котра дозволила вчасно провести місиеві вибори за новими правилами (вибори відбулись 25 жовтня 2020 року).

Важливими є також співучасть і допомога країн Західної Свропи на всіх етапах реформи децентралізації влади в нашій державі, на різних рівнях. Зокрема віце-прем'єр-міністр федеральної землі Саксонія (ФРН) Георг Мілбрадт під час виступу на згаданому форумі зауважував, що вони «вітають розвиток співпраці на базовому рівні українських територіальних громад зі своїми партнерами в С» $^{10}$. Доповідаючи він також наголошував: окремі країни

8 Бойко Володимир. Повертаємось до плану «Б»? - [Електронний ресурс]. Режим доступу до доерела: $\quad$ https://m.day.kyiv.ua/uk/article/svitovidyskusiyi/povertayemos-do-planu-b

9 Бойко Володимир. Повертаємось до плану «Б»? - [Електронний ресурс]. Режим доступу до доерела: $\quad$ https://m.day.kyiv.ua/uk/article/svitovidyskusiyi/povertayemos-do-planu-b

10 Бойко Володимир. Повертаємось до плану «Б»? - [Електронний ресурс]. Режим доступу до до джерела: https://m.day.kyiv.ua/uk/article/svitovidyskusiyi/povertayemos-do-planu-b. 
СС зацікавлені в тому, щоб реформи відбулися і підтримують всі процеси власним досвідом, кадровим потенціалом та фінансово, проте громадяни повинні самостійно вирішувати питання необхідності реформи децентралізації в Україні.

Слушною, на наш погляд, виявилась також думка німецького експерта про надмірну тривалість періоду добровільного створення об'єднаних територіальних громад, оскільки існували певні дедлайни, позаяк місцеві вибори мали відбутися в жовтні 2020 року, а це теж потребувало відповідної підготовчої роботи (по суті, після Постанови Верховної Ради від 17 липня 2020 p. часу практично не залишилось). Враховуючи, що адміністративнотериторіальна реформа досі не прийшла до свого логічного завершення, суспільство разом з урядом повинне дослухатися до порад міжнародних фахівців і докласти максимум зусиль для досягнення позитивного результату щодо ухвалення остаточного адміністративно-територіального устрою України в найближчі роки. Поки що нам залишається лише вірити, що «така комплексна реформа, за твердженням Георга Мілбрадта, докорінно змінить державу Україна, котра будуватиметься «знизу», а не «згори». Це принципово відрізнятиме Україну від Росії. Зміна способу публічного управління на європейський означатиме кінець «русского мира» в Україні»11.

Зважаючи на сучасну ситуацію варто все ж таки зазначити, що реформування влади є актуальною проблемою як для уряду, так i для парламенту, які намагалися попри всі обставини реалізувати заплановані заходи на користь країни та громадян. Крім того, варто зазначити: вдалого об'єднання територіальних громад неможливо було б досягнути без допомоги та підтримки національних та іноземних донорів, зокрема таких, як ЄС та США, які стимулювали реформи за допомогою програм ULEAD, PULSE та DOBRE, значно покращивши результативність реформи децентралізації в Україні. Важливу роль у процесах впровадження конституційних та юридичних змін відіграли також міжнародні організації, зокрема Рада Європи в рамках проекту «Децентралізація і реформа місцевого самоврядування в Україні».

Саме завдяки окресленим вище організаціям та їх супутній допомозі нині територіальна консолідація об'єднаних громад та розширення можливостей місцевого самоврядування є головними досягненням децентралізації за останні

11 Бойко Володимир. Повертаємось до плану «Б»? - [Електронний ресурс]. Режим доступу до домерела: https://m.day.kyiv.ua/uk/article/svitovidyskusiyi/povertayemos-do-planu-b. 
5 років. Важливо, що об'єднання всіх існуючих територіальних громад, відбувалося на добровільній основі, що є яскравим підтвердженням розвитку місцевої демократії в Україні. Крім того, це свідчить про поступальних рух «провінційної» України вперед і тому життєво необхідним в сучасних умовах є забезпечення такого рівня державного нагляду за законністю рішень органів місцевого самоврядування, який би не заважав регіональному та субрегіональному самоврядуванню. Задля цього, Парламенту ще до остаточного реформування адміністративно-територіального устрою України необхідно визначити майбутні функції самоврядування як на обласному так і на районному рівнях, а також відокремити від вимог Мінських угод необхідні для децентралізації та прийняти необхідні конституційні та інші правові зміни, щоб якнайшвидше продовжити реформи. I будемо сподіватися, що на другому етапі реформи міжнародні організації та приватні донори не залишать Україну на півшляху і так само рішуче будуть підтримувати всі процеси. Відтак, будемо сподіватися на фрілософський підхід до проиесів реформування місцевого самоврядування.

Висновки та перспективи подальших досліджень. Підсумовуючи результати нашого теоретичного екскурсу, зауважимо: основними викликами для реформи децентралізації влади в Україні завжди виявлялись невідповідність амбітної програми авторів реформи обмеженій інституційній спроможності виконання політичних рішень (особливо у попередньо визначені терміни 2014-2017 рр.). Незважаючи на те, що починаючи від подій Свромайдану влада й уряд України показували значні організаторські здібності та бажання розпочати реформи, незважаючи на внутрішні виклики територіальній цілісності й масштабні зовнішні загрози, ми й донині не можемо говорити про позитивну реалізацію планів.

Якщо з боку громадськості та суспільства вдалося досягнути позитивних результатів, що підтверджує значна кількість об'єднаних територіальних громад, які з'явилися на території нашої держави, тоо політичні лідери та представники політичної еліти зазвичай здійснювали опір зазначеним процесам, зокрема в парламенті, перешкоджаючи внесенню законодавчих змін щодо децентралізації в Конституцію України. Останнє призвело до унеможливлення впровадження нової адміністративної структури та відповідного територіального поділу країни. Відповідно, замість того, щоб у визначені терміни мати відповідні позитивні досягнення, ми можемо говорити лише про помітні зміни на місцевих рівнях й про відсутність правового оновлення Української Держави. 
PhD in Pedagogical Sciences Dmitry Verbivsky (Zhytomyr, Ukraine),

Dr. habil. Prof. Kostiantyn Vergeles (Vinnitsya, Ukraine),

PhD in Philosophy Lyudmila Horokhova (Zhytomyr, Ukraine)

\section{Decentralization in Action: Political, Philosophical and Legal Aspects}

The article offers the author's analysis and assessment of the features of the practical implementation of the reform of local self-government in Ukraine. The features of the political, philosophical and legal aspects of the decentralization of power in modern conditions have been investigated. The achievements and shortcomings of decentralization at the constitutional level, the issues of the scale, speed, consequences and obstacles of reforming local self-government, the attitude of the public and the authorities to the outlined processes on the way of distributing public power (state and local), as well as on the way of creating effective united territorial communities are analyzed.

Key words: Decentralization of Power, Reform of Local Self-Government, Administrative \& Territorial Structure, Constitutional and Legal Basis, Political Aspects of the Reform, Regulatory Support.

кандидат педагогических наук Дмитрий Вербивский (Житомир, Украина), доктор философских наук Константин Вергелес (Винница, Украина), кандидат философских наук Людмила Горохова (Житомир, Украина) Децентрализация в действии: политические, философские и юридические аспекты

В статье предложены авторские анализ и оценка особенностей практической реализации реформирования местного самоуправления в Украине. Исследованы особенности политических, философских и юридических аспектов децентрализации власти в современных условиях. Проанализированы достижения и недостатки децентрализации на конституционном уровне, вопросы масштабов, скорости, последствий и препятствий реформирования местного самоуправления, отношение общественности и власти к очерченным процессам на пути распределения публичной власти (государственной и местной), а также на пути создания действенных объединенных территориальных общин.

Ключевые слова: децентрализация власти, реформирование местного самоуправления, административно-территориальное устройство, конституционно-правовой базис, политические аспекты реформы, нормативно-правовое обеспечение. 
кандидат педагогічних наук Дмитро Вербівський (Житомир, Україна), доктор філософських наук Костянтин Вергелес (Вінниця, Україна), кандидат філософських наук Людмила Горохова (Житомир, Україна) Децентралізація в дії: політичні, філософські та юридичні аспекти У статті авторами запропоновано аналіз та оцінку особливостей практичної реалізації реформування місцевого самоврядування в Україні. Досліджено особливості політичних, філософських та юридичних аспектів децентралізації влади в сучасних умовах. Проаналізовано досягнення i недоліки децентралізації на конституційному рівні, питання масштабів, швидкості, наслідків та перешкод реформування місцевого самоврядування, ставлення громадськості та влади до окреслених процесів на шляху розподілу публічної влади (державної та місцевої) й створення об’ єднаних територіальних громад. Ключові слова: децентралізація влади, реформування місцевого самоврядування, адміністративно-територіальний устрій, конституційноправові засади, політичні аспекти реформи, нормативно-правове забезпечення.

* Вербівський Дмитро Сергійович - кандидат педагогічних наук, доцент кафедри прикладної математики та інформатики Житомирського державного університету імені Івана Франка.

* Вергелес Костянтин Миколайович - доктор філософських наук, доцент, професор кафедри філософії та суспільних наук Вінницького національного медичного університету імені М. І. Пирогова.

* Горохова Людмила Вікторівна - кандидат філософських наук, доцент, доцент кафедри філософії та політології Житомирського державного університету імені Івана Франка.

E-mail: kvergeles@gmail.com. 